case of the older observatories to adhere to the same system of observing hitherto in use; until at least four or five years' observations have been made simultaneously with a second set of instruments placed in uniformity with those of other observatories.

The question of the practicability and utility of Veather and Storm Signals in Europe was considered, and it was remitted to Messrs. Buys Ballot, Scott, and Neumeyer, to collect the opinions of metcorologists on this important question, and draw up a report for the Vienna Congress. As it is understood that the committec have collected a good deal of information, some valuable results may be expected.

In the "Sequel to the Suggestions," Dr. Buys Ballot has suggested for the consideration of the Congress, the establishment, by societies, of stations in regions which are at present a blank. The Smithsonian Institution, the Dutch Meteorological Institute, and, in our country, the Scottish Meteorological Society have, with the means at their disposal, done a good deal in this direction, with results which have aided much in the furtherance of the science. But to fill up the enormous blanks which still disgrace British America, South America, most of Africa, and the Pacific, some concerted action on the part of meteorologists is indispensable. In connection with this proposed development, reference may be made to the scheme in contemplation by the Chinese Government, in carrying out which Mr. Campbell has been sent to this country to request advice from scientific authorities as to the general crganisation of the stations, and to procure the necessary instruments, registers, \&c. Towards the carrying out of this plan, the Congress will doubtless give Mr. Campbell very hearty support.

\section{THE TYPHOID EPIDEMIC IN LONDON}

THE

$\mathrm{E}$ recent outbreak of enteric fever in the West End of London presents many points of remarkable interest and teaches many useful lessons. Typhoid, Enteric, or Pythogenic fever, although a disease about which all our accurate knowledge is quite recent, is a fever about the causes of which we really know a great deal, but which, for all that, seems to appear from time to time in the places where it might be least expected.

About the nature of the poison which produces it we know as yet but little; we know that its habitat is in the refuse matters excreted from human intestines; we know that it is, under certain circumstances, developed in such excretal matters during their decomposition, but it is yet a moot point whether it is from time to time produced de nowo under suitable conditions, or whether it is always necessary that some of the poison, however small a quantity, be introduced from without to cause such de. composing matters to become infectious. We are accustomed to regard this as the least specific of the discases of its kind, but each outbreak which is traced to its source gives a rude shock to such ideas. The "filth-born" fever bar cxcellence, it ought not, one would think, to need to wait to be introduced to the country places where, year after ycar for centuries, the shallow wells from which drinking water is obtained are, in effect, the drains of the premises; or to the town houses, in which the only ventilator to the sewer is the waste pipe which opens directly over the surface of the water in the cistern; but yet such is the case so universally, that when we cannot find out how the poison has been introduced, we should acknowledge our inability to do so, and not cut the knot by saying that it has originated on the spot, a conclusion for which, in the present state of our knowledge, we have no real proof whatever. The number of instances in which epidemics have been traced to single imported cases is now so great that, although it does not actually prove that such is always the case, still it should make us hesitate before declaring that the disease has broken out without direct importation in any given place.

The facts relating to the epidemic which still engages general attention in England, are, in order of sequence, and independently of any theory at all, as follows :-

The disease was noticed to be prevalent, in the middle and latter part of July, in certain houses in the parish of Marylebone, and notably in houses inhabited by medical men, houses where cvery possible precaution was believed to have been taken : it was observed by Dr. Murchison that an undue proportion of the persons attacked obtained their milk from a particular dairy, and on further investigation the conviction grew upon him that this milk was, somehow or other, contaminated with typhoid poison, and was spreading the disease. A difficulty arose, inasmuch as the locality in which the fever cases were was only a small part of the district supplied with milk from the suspected dairy; but MIr. Radcliffe, on examining the mode of distribution of the milk, showed that on the hypothesis that the milk from one of the several farms was contaminated before coming to the dairy, a localised outbreak or several localised outbreaks of fever must have been the result; so that any suspicion which may have existed as to the cause being possibly to be found in the precincts of the dairy in London, vanished at once.

On the other hand it was found that the owner of one of the dairy-farms had died on June $S$; that he had been out of sorts since early in May, and sufficiently so for his two medical men to consult with a third on the subject ; that the medical men all suspected that he had enterîc fever; that this suspicion became stronger when the patient passed a large quantity of blood and putrid matter on June $I$, which blood, \&c., was ordered to be buried away from the house, as being most probably infectious; that the patient became considerably better towards the cnd of the first week of June, but that he died suddenly on June 8 while getting out of bed, no medical man being present; and finally that the medical attendant not being sure of the diagnosis of enteric fever, and considering that, anyhow, the man had got over it, certified that he died from heart disease, as he had for years been suffering from the effects of a "fatty heart;" nevertheless he took the precaution to have the body buried as speedily as possible, thinking that it might be infectious.

Taking all the facts together, these two series of events present at any rate a most remarkable coincidence; and when we find that enteric fever is and has for some months been prevalent in the villages near the farm and in daily communication with it, and that a son of the farmer has since had the disease, the conclusion is irresistible that the farmer died of enteric fever, and that he 
had it at a time most singularly adapted to account for the outbreak in London.

The description of the farm-yard itself has been given elsewhere; suffice it to say that the well really drained the premises, and there is little doubt but that the poison got into the water, which was so bad that it had long been condemned as unfit to drink.

Hitherto epidemics of typhoid spread by means of milk have been attributed to the admixture of water as an adulteration with it ; in this case no such suspicion arises, the milk was exceptionally rich, and was daily tested with sufficient accuracy to show adulteration with any but a small amount of water; but the water from the well was conveyed to the dairy pump by a pipe, and was used for washing the dairy utensils, so that it is easycto account for the presence of a small amount in some of the "churns," an amount, however, enough in so favourable a pabulum as milk to infect a very large quantity of it.

The lesson to be drawn is that all dairy-farms must be subject to regular sanitary supervision, especially as to their water supply, that such details of arrangement with regard to the cleansing of the vessels as may seem to offer least chance of the possibility of mischief should be adopted, and that the presence of infectious disease among the employés should be noted at once, and the proper precautions, which are now well known, taken.

\section{W. H. CORFIELD}

DOLMEN-MOUNDS v. FREE-STANDING AND TRIPOD CROMLECHS

$M R . W . C O P E L A N D$ BORLASE, the talented author of "Nænia Cornubix," in his communication to NATURE (vol. viii. p. 202), calls attention to the structure of Lanyon Quoit as an undeniable example of a British tripod cromlech or free-standing dolmen, by way of "protest against the dictum of Mr. Lukis being extended to our British examples, before a careful scrutiny has been made of every monument of the kind, from one corner of our isles to the other."

To my friend Mr. Borlase I owe my personal acquaintance with the numercus non-historic rude stone monuments in the Land's End district ; and, as he is a life-long resident in the immediate vicinity of these interesting relics, to which I am a mere casual visitor, it is with feelings of great delicacy and diffidence that I now venture to place in a somewhat different aspect the statements and conclusions which he would wish your readers to adopt.

It were strange if MIr. Borlase did not turn out the best authority on early Cornish remains, for within six or seven miles of his residence at Castle Horneck (itself the site of an ancient Cornu-British encampment) there are at least twice as many dolmens as in all the rest of England ; and though there may be perhaps as many in Anglesea, and twice as many in Wales, still West Cornwall has an advantage over both these districts, viz., that in Wales and Anglesea, the country of the Silures, there are no circles but only dolmens; in Cornwall, as in the Isle of MIan, there are both circles and dolmens, the result, as Fergusson tells us, of an Ibero-Aquitanian admixture with Celtic and other (Scandinavian ?) blood in the inhabitants. (Vide "Rude Stone Monuments," p. 163.)

Inheriting the tastes and following in the footsteps of his grcat-grandfather of antiquarian renown, Mr. Borlase has made great use of his opportunities, and is continually adding to, or accumulating store of facts with regard to the ancient history of our country. On the other hand, most antiquarians will probably agree with $\mathrm{me}$ in maintaining that the Lukis family may be reckoned some of the best, if not the very best authorities, on the chambered barrows of France and the Channel Islands. Enormous numbers of these structures have been scicn. tifically examined and exhaustively described by the Messrs. Lukis : and the Rev. W. Lukis, in company with Sir Henry Dryden, is now employed in drawing to scale plans and elevations of the Isle of Man remains, and thereby carrying out his share of that scrutiny which Mr. Borlase anxiously demands in his letter.

When such authorities disagree, it would seem almost impertinent to interfere ; but knowing my friend $\mathrm{Mr}$. VV. Lukis to be busily engaged in the Isle of Man, and too far off to personally examine the monument in dispute, whilst I was within a three hours' journey of the structure I determined to see the cromlech myself, and having done so, cannot allow Mr. Borlase's letter to remain un. challenged.

In taking up the cudgels for Mr. Fergusson, Mr. Borlase must not be looked upon as an implicit follower of that author, whose work he characterises as "1tureliable,"* although, with him he is convinced "that the barrows and the cromlechs (if not the circles too) were the sepulchres of the dwellers in the hut circles and the earthworks; and that these latter were the residences of the Romanised Britons in the earlier centuries of the Christian era ;" for before the appearance of "Rude Stone Monuments," he struck out for himself the formation of " a small class or species of dolmen," viz. the tripod cromlech, or dolmen proper (see "Nænia Cornubix," p. I4, et seq.), "where, as Col. Forbes Leslie remarks, "the vertical' supporters of the tabular stone are columnar,' and cannot be said to enclose a space."

Before proceeding, it may be as well to remark what Mr. Borlase ignores, viz. that (as may be seen from the title to his paper) the criticism of Mr. Lukis (deserved, if severe) of "Rude Stone Monuments," was based upon the application of the "Free-standing" theory, by the author, to the monuments of France, where he proved it was inapplicable. He said nothing at Somerset Housc about English monuments, although I believe it is his intention to say something about them on a future occasion. Mr. Borlase severely attacks Mr. Lukis, as though, in removing the French monuments from the supposed "free. standing class, he condemned all persons who held their own views on British ones. MIr. Lukis' views are not "hypotheses." He simply declares that the plans of French monuments which he produced before the Society of Antiquaries in London teach the proposition he laid down, and that it is the duty of those who are unacquainted with these examples to verify or disprove his statements and descriptions by visiting and inspecting them, and not to try and write him down when they have a very imperfect knowledge of them, or none at all. Previous to taking stock of Mr. Borlase's weighty evidence in support of Lanyon Quoit as originally a dolmen proper, i.e. a tripod cromlech, it should be noted what Fergusson states in respect to the West of England dolmens. In "Rude Stone Monuments," p. 163, he says : "Even a cursory examination of these West Coast dol. mens would, I think, be sufficient to prove to any one that the theory that all were originally covered with earthen mounds is utterly untenable." Exactly so! A cursory examination (which, if we are to believe MIr. Borlase, it appears that Fergusson never took the trouble to make, at least as regards the Cornish circles) $\dagger$ is very likely to lead the uninitiated hasty observer to suppose as above. What a prolonged investigation will prove I leave the reader to find further on. It is, at all events, unfortunate for this theory that Mr. Borlase can only produce two $\neq$

* See Mr. Borlase's letter to the Antiquary, July 27, 1872.

$\dagger$ Letter to the Antiquary. July 27,1872 .

I Mr. Borlase mentions a pussible third example, in his "Nania," p. 26 A fallen cromlech, which may have possibly belonged to the "tripod class," is to be found near Helmen Tor, in the parish of Lanlivery. 